\title{
Dekker and the virgin martyr
}

\section{W. A. Ovaa}

To cite this article: W. A. Ovaa (1921) Dekker and the virgin martyr, English Studies, 3:1-6, 167-168, DOI: $10.1080 / 00138382108596423$

To link to this article: http://dx.doi.org/10.1080/00138382108596423

曲 Published online: 13 Aug 2008.

Submit your article to this journal $\pi$

LII Article views: 1

Q View related articles $\asymp$ 


\section{Dekker and The Virgin Martyr.}

With reference to the questions broached by Mr. van Doorn in English Studies, Vol. III, No. 3, pag. 88, the following remarks may be of some value. There is first of all his query about the authorship of. The Virgin Martyr. Now in: A. W. Ward, Old English Drama, 1901, Appendix A, contributed by F. G. Fleay, page CLXIX, this statement appears:

"When the Admiral's men acted in London we find among the old plays revived by them Dioclesian (The Virgin Martyr)" and in a footnote to this:

"When my Life of Shakespeare was printed I had not tracked this play so far and it was mentioned as an exception. It reappears in Germany in d652 (see Cohn, Shakespeare in Germany, CXVIII) as "a comedy of the aemperor Diocletian, with Maximinus and the shoemaker. Hirtius is a shoemaker In The Virgin Martyr, and Diocletian and Maximus are principal characters In the play. Dekker's original play seems to have been called Diocletian, Cor Dorothea, and the play, as revised by Massinger: The Virgin Martyr"'. - A statement to the same effect is made by F. E. Schelling in: The English TDama, 1914, page 196: “The appearance of Massinger's name with Dekker's in The Virgin Martyr, licensed in 1620, and reckoned among the earliest of Fis plays, and with Middleton's and Rowley's in The Old Law, doubtless marks his revision of the older original work of these playwrights."

So it seems to be an accepted fact that Dekker was the original author off the play in question, though it may have borne another name. This settled we may now deal with the origin of the story. Mr. v. D. says: "In Imy opinion this drama owes more than a little to El Mágico Prodigioso Wy Calderon de la Barca. Were any translations of this play available, in Fnglish or in French? Are there any indications that Massinger or Dekker Gnew Spanish?"

With respect to the latter question, I will only quote what Schelling says in the above-mentioned work, page 188:

"Spanish authors upon whom Fletcher levied with his collaborator Massinger . or their tragi-comedies, are Lope de Vega for The Pilgrim, etc..... Spanish, are underplots, episodes and personages in Rule $a$ Wife and Have a Wife, etc..... It is of interest to note that in the list of some 18 plays of Fletcher which have been referred to Spanish origin..... not one is derived from a Spanish play, but all come from Spanish prose fiction. FSecondly there is not one of these Spanish stories that had not been translated, toy Fletcher's time, either into French or into English; so that the assumption Ghat FI. was acquainted with the Castilian tongue is as hazardous as the Fassignment to Shakespeare of a familiar knowledge of Italian." On pag. 256 one remarks: ".... it is not necessary to infer on Fletcher's part - or on that of Massinger or Rowley, .... either an acquaintance with the Spanish language or any knowledge of the Spanish stage."

And as to Mr. v. Doorn's suggestion that The Virgin Martyr should owe not a little to El Mágico Prodigioso, a simple comparison of dates will prove that it is not tenable, since Calderon (1600-1681) wrote this play in 1637. Now Dekker's Diocletian (or Dorothea), according to Ward, must have been written before 1592, and Massinger's Virgin Martyr appeared in 1620 , so how could they have availed themselves of the Spanish play or of a translation? No, both these plays spring from a common source and I venture to suggest that it was especially due to Massinger's revisions that this Faust-motif was added to Dekker's play, which provided him with the comical element, also present in Calderon in the shape of the two 
gracioso's. And we can easily understand Massinger appropriating this motif, since it gave him an opportunity to write a Roman Catholic play.

The question now to be solved is: Did $C$. and $M$. use the same source a well-known mediaeval story of martyrology, to wit the legend of St. Cyprian, which had already been used as early as the beginning of the $5^{\text {th }}$ century by the Greek poetess Athenais $(+420$ at jerusalem) for an epic poem in 3 cantos. But there was also a later Latin version, as see Busse, Das Drama, I, page $80(1910)$.

"In The Virgin Martyr bemülit sich der glaubenseifrige Konvertit, ein neukatholisches Mirakelspiel zu dichten, wie es gleichzeitig die Jesuiten in lateinischer, die Spanier in ihrer Muttersprache schufen."

Was this perhaps the story to be found in: Breviarum Romanum, dic XXVI September, in festo S. S. Cypriani et Justinae? This question must for the present remain unsolved.

Rotterdam.

W. A. OVAa.

\section{Critical Contributions to English Syntax. \\ $\mathrm{XI}$.}

\section{Form and Function of Sentences.}

In analysing sentences it is usual, and proper, to consider form first, function in the second place. Sometimes form and fuction disagree completely. We find

1. apparent simple sentences, which are double or compound in function.

2. apparent coordinate sentences or parts of sentences.

3. apparent compound sentences which are simple or double sentences in their function.

4. apparent subordinate clauses which have the function of independent sentences.

Apparent Simple Sentences.

Sentences with free adjuncts are usually treated as simple sentences. But the absence of a finite verb is not really a final test in deciding whether we have a real sentence, and as far as function goes the free adjuncts may very well be considered to be parts of a double or compound sentence. When the relation between a free adjunct and the rest of the sentence is one of attendant circumstances the whole may be considered a double sentence. In other cases it is rather a compound sentence.

We have a similar case in sentences with some adverbs. In the sentence Unfortunately he could not speak a word of German the adverb unfortunately does not qualify any part of the sentence, nor does it qualify the sentence as a whole, but it expresses an independent thought: It was unfortunate. These adverbs may be called sentence-adverbs.

It is impossible to say whether sentences with such adverbs are double or compound sentences. When they are connected by and the effect may be that of a parenthetic sentence.

He has protested, and rightly, against the inability of biographers, notoriously Macaulay, "to conceive of conduct except as eitlier right or wrong". Times Lit. $10 / 2,21$.

\section{Apparent Coordination.}

It is not always easy to decide whether we have a double sentence or a simple sentence with a double subject or predicate. The following two sentences show how gradually one construction passes into the other. 